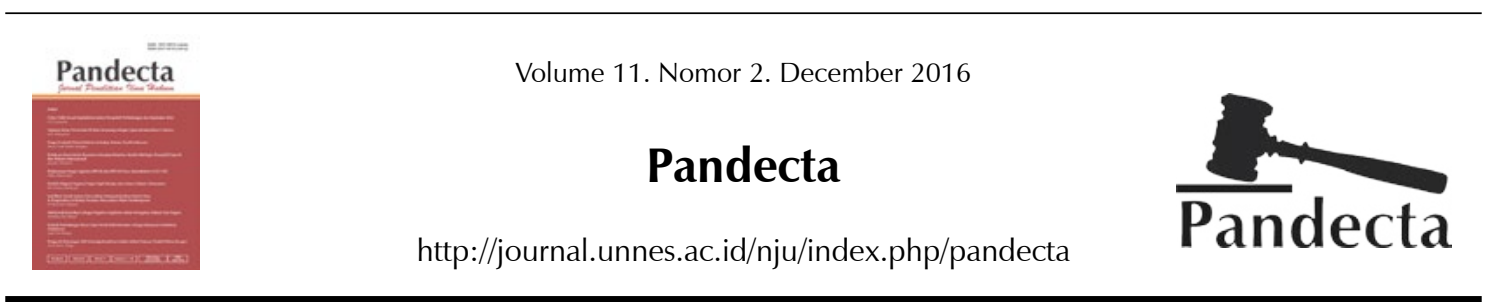

\title{
Fondasi Ilmu Hukum Berketuhanan: Analisis Filosofis terhadap Ontologi, Epistemologi, dan Aksiologi
}

\author{
Mahrus Ali $\bowtie$ \\ Fakultas Hukum Universitas Islam Indonesia, Yogyakarta \\ DOI: http://dx.doi.org/10.15294/pandecta.v11i2.7844
}

\begin{tabular}{l} 
Info Artikel \\
\hline Article History: \\
Received : June 2016; \\
Accepted: November 2016; \\
Published: December 2016 \\
\hline Keywords: \\
Pancasila; Cod's law; ontol- \\
ogy; epistemology; axiology
\end{tabular}

Abstrak

Ketuhanan Yang Maha Esa ditempatkan sebagai sila pertama Pancasila. Implikasinya, pembaharuan, pembentukan, dan penegakan hukum di Indonesia harus bersumber pada nilai yang terkandung di dalam sila pertama tersebut. Penelitian ini bertujuan untuk secara filosofis menganalisis ontologi, epistemologi, dan aksiologi ilmu hukum berketuhanan. Penelitian ini merupakan penelitian hukum normatif dengan pendekatan filosofis dan konseptual. Hasil penelitian ini mengungkap bahwa hakikat ilmu hukum berketuhanan adalah ilmu hukum yang dikembangkan berbasis pada nilai-nilai ketuhanan. la bukanlah ilmu hukum yang sekuler yakni ilmu hukum yang melepaskan diri nilai-nilai moral dan agama, melainkan ilmu hukum yang menjadikan nilai-nilai moral dan agama sebagai fondasi dalam pembaharuan, pembentukan, dan penegakan hukum. Kebenaran pengetahuan menurut ilmu hukum berketuhanan beranjak dari kebenaran firman Tuhan yang diwujudkan dalam bentuk nilainilai Pancasila yang selaras dengan nilai-nilai budaya bangsa Indonesia. Kebenaran di sini tidak hanya mengacu kepada kebenaran korespondensi, kebenaran koherensi, dan kebenaran pragmatis, tapi juga menjadikan ketiganya menyatu di bawah payung kebenaran ilahiah. Sedangkan nilai yang hendak diwujudkan oleh ilmu hukum berketuhanan sedemikian komperensif yang memuat semua nilai-nilai bangsa Indonesia baik yang religius maupun yang kultural. Nilai-nilai ini sudah dipraktikkan sejak lama oleh bangsa Indonesia sebelum merdeka. Meskipun nilai-nilai itu universal dan abstrak, tapi ia sudah mendarah daging dan menjiwai kehidupan sehari-hari bangsa Indonesia.

\begin{abstract}
Believing in the only and one God is set as the first pillar of Pancasila. This will have an implicate that the law reform, law making, and law enforcement must refer to the values. This article is aimed at analysing the ontology, epistemology, and axiology of God law. This research is normative legal research, white the approach used is both philosopical and conceptual. This article reveals that the essence of God law is the law founded by the values of God. It combines the values of morality and religion. The truth of knowledge stands from the truth of God's sayings and is manifested in the form of values of Pancasila which are in accordance with the cultural values of Indonesia. The absolute truth of God's sayings is a combination of correspondence, coherence, and pragmatic rightness. Finally, the value directed by the God's law is so comprehensive consisting all Indonesian values religiously and culturally which have been practised at long time. Although these values are universal dan abstract, they have been embedded in the soul and daily life of Indonesian people.
\end{abstract}




\section{Pendahuluan}

Idealnya, hukum suatu negara harus sesuai dengan nilai-nilai budaya dan mencerminkan kepribadian masyarakatnya. Hukum yang diberlakukan di suatu negara yang diimpor dan berasal dari negara lain seringkali tidak sesuai dengan pandangan hidup negara itu. Adanya perbedaan nilai di antara keduanya menyebabkan hukum tidak mampu mewujudkan tujuan tertinggi (the ultimate goal) hukum, yaitu keadilan. Karena setiap negara, sebagiamana dikemukakan Satjipto Rahardjo, memiliki karakter dan cara hukum yang berbeda satu sama lain yang didasarkan pada nilai-nilai dan pandangan hidup masyarakat (Raharjo, 2007), maka nilai-nilai dan pandangan hidup tersebut mutlak dijadikan sebagai sumber hukum materiil utama dalam pembaharuan dan pembentukan hukum.

Sebagai negara yang menjadikan Pancasila sebagai nilai-nilai dan pandangan hidup bangsa (Kealan, 2004; 107), pembaharuan, pembentukan dan penegakan hukum di Indonesia harus bersumber pada nilai-nilai Pancasila dengan kelima silanya yang berkaitan satu sama lain. Penempatan 'Ketuhanan Yang Maha Esa' sebagai sila pertama Pancasila berimplikasi pada adanya pergeseran perspektif dalam memaknai ilmu hukum Indonesia; dari ilmu hukum yang berbasis pada akal-budi manusia ke ilmu hukum yang bersandar pada nilai-nilai ketuhanan. Adanya pergeseran perspektif tersebut menuntut adanya usaha ilmiah untuk menggali dan menemukan ilmu hukum berketuhanan yang merupakan ciri khas ilmu hukum Indonesia dengan menekankan pada sisi ontologi, epistemologi, dan aksiologinya.

Tulisan ini merupakan ikhtiar ke arah itu. Ada dua alasan mengapa ilmu hukum yang perlu dikembangkan di Indonesia adalah ilmu hukum yang berbasis kepada nilainilai ketuhanan. Pertama, kemerdekaan Indonesia yang diraih pada tahun 1945 dari tangan penjajah tidak hanya dimaknai sebagai kemerdekaan secara fisik, tapi juga diperluas kepada kemerdekaan politik, ekonomi, budaya, dan termasuk hukum. Setelah Indonesia merdeka, maka hukum harus dijiwai dengan nilai-nilai Pancasila. Karena Ketuha- nan Yang Maha Esa ditempatkan sebagai sila pertama Pancasila, maka logis bila ilmu hukum Indonesia merupakan ilmu hukum yang berbasis kepada Ketuhanan Yang Maha Esa.

Kedua, Seminar Hukum Nasional Ke-I sampai Ke-VII minus Ke-V selalu menjadikan Pancasila dengan lima nilai yang menyertainya sebagai dasar dalam pembaharuan sistem hukum nasional (Seminar Nasional Tahun 1963, 1968, 1974, 1979, 1994, dan Tahun 1999). Bahkan, secara radikal ditegaskan bahwa pelaksanaan Undang-undang Dasar 1945 yang berlawanan dengan semangat dan jiwa Pancasila berarti manipulasi konstitusi dan pengkhianatan terhadap Pancasila (Seminar Hukum Nasional Tahun 1968). Jika dikaitkan dengan ilmu hukum berketuhanan, pengembangan ilmu hukum Indonesia yang tidak berbasis pada nilai-nilai moral dan religius adalah manipulasi konstitusi dan pengkhianatan terhadap Pancasila.

Berdasarkan uraian di atas, permasalahn dalam penelitian adalah bagaimana ontologi, epistemologi, dan aksiologi ilmu hukum berketuhan? Bagaimana perbandingan antara ontologi, epistemologi, dan aksiologi ilmu hukum berketuhan dengan aliran-aliran dalam filsafat hukum yang berkembang di dunia Barat Amerika dan Eropa? Penelitian ini bertujuan untuk mencari, menemukan, dan menganalisis ontologi, epistemologi, dan aksiologi ilmu hukum berketuhanan dan membandingkannya dengan aliran-aliran dalam filsafat hukum yang berkembang di dunia Barat Amerika dan Eropa.

\section{Metode Penelitian}

Penelitian ini merupakan penelitian hukum normatif karena yang dikaji adalah asas keadilan dalam sistem moral khususnya ontologi, epistemologi, dan aksiologi ilmu hukum berketuhan (Wignjosoebroto, 2002; 147-176). Pendekatan yang digunakan adalah pendekatan filosofis, konseptual, dan perbandingan hukum. Bahan hukum dikumpulkan melalui studi literatur. Sedangkan analisis penelitian dilakukan secara deskriptif kualitatif, dalam arti bahan hukum diuraikan dalam bentuk narasi yang tersusun secara sistematis, logis, dan merupakan hasil dari proses inter- 
pretasi peneliti terhadap bahan hukum yang dihasilkan (Miles dan Huberman,tt; 16).

\section{Hasil Penelitian dan Pembahasan}

\section{Pancasila Sebagai Cita Hukum dan Pan- dangan Hidup Bangsa}

Cita hukum (rechtsidee) berisi ide hukum yang telah diramu dalam kesatuan dengan nilai yang berasal dari kategori nilai lainnya yang menunjukkan pula sejauhmana fenomena kekuasaan terintegrasi padanya (Siti Soendari dan Agni Udayati, 1996; 61). Cita hukum dalam konteks ini mengandung arti bahwa pada hakikatnya hukum sebagai aturan tingkah laku masyarakat berakar pada gagasan, rasa, karsa, cipta dan pikiran dari masyarakat itu sendiri. Jadi, cita hukum adalah gagasan, karsa, cipta dan pikiran berkenaan dengan hukum atau persepsi tentang makna hukum, yang dalam dirinya terdiri atas tigas unsur, yaitu keadilan, kehasilgunaan, dan kepastian hukum. Cita hukum itu terbentuk dalam pikiran dan sanubari manusia sebagai produk berpadunya pandangan hidup yang diproyeksikan pada proses pengkaidahan perilaku dalam masyarakat yang mewujudkan tiga unsur tersebut (Sidharta, 2000; 181).

Dalam dinamika kehidupan kemasyarakatan, cita hukum itu akan mempengaruhi dan berfungsi sebagai asas umum yang mempedomani, norma kritik dan faktor yang memotivasi dalam penyelenggaraan hukum. Dirumuskan dan dipahaminya cita hukum akan memudahkan penjabarannya ke dalam berbagai perangkat aturan kewenangan dan aturan perilaku dan memudahkan terjaganya konsistensi dalam penyelenggaraan hukum. Dengan demikian, seyogianya tata hukum merupakan sebuah eksemplar ramifikasi cita hukum ke dalam berbagai kaidah hukum yang tersusun dalam suatu sistem (Sidharta, 2013; 96).

Cita hukum memiliki dua segi, yaitu segi materiil dan segi formil. Segi pertama berisi satu kesatuan nilai-nilai dari kategori nilainilai lainnya termasuk fenomena kekuasaan, menurut cita dan rasa budaya masyarakat yang bersangkutan. Sedangkan segi kedua merupakan suatu wadah dari cita hukum yang telah digunakan untuk memperhitungkan alam kenyataan di sekitar masyarakat yang bersangkutan (Soendari dan Udayati, 1996; 61). Cita hukum bangsa Indonesia berakar pada Pancasila yang oleh Bapak Pendiri Negara Republik Indonesia ditetapkan sebagai landasan kefilsafatan dalam menata kerangka dan struktur dasar organisasi negara sebagaimana yang dirumuskan dalam Undang-undang Dasar 1945.

Dengan dijadikannya Pancasila sebagai cita hukum, eksistensinya tidak hanya berupa cita-cita dalam angan-angan, melainkan telah mempunyai bentuk dan isi formal dan materiil untuk menjadi pedoman bagi hidup kenegaraan dan hukum Indonesia (Notonegoro, 1980; 174). Pancasila berisi nilai-nilai dasar atau nilai-nilai fundamental, yaitu nilainilai yang terdapat di dalam rumusan sila-sila Pancasila yang bersifat abstrak dan universal. Nilai-nilai itu adalah nilai religius, nilai kemanusiaan, nilai persatuan bangsa, nilai kerakyatan, dan nilai keadilan sosial (Soejadi, 1999;87-90, Wahana, 1993; 72-75).

Agar nilai-nilai yang terkandang di dalam Pancasila dapat diwujudkan, eksistensinya hendaknya dijadikan sebagai sumber inspirasi dan menjadi penuntun ke arah yang hendak dituju oleh hukum nasional. Oleh karena itu, (ilmu) hukum nasional hendaknya secara hakiki memuat sikap menjunjung tinggi agama, moral, etika, harkat dan martabat manusia, mencerminkan jiwa dan rasa keadilan manusia dan masyarakat, dan disusun dengan berpedoman pada pandangan hidup dan kepribadian serta aspirasi yang hidup dan berkembang di dalam masyarakat (Azed, 1989; 93-94).

Pancasila, selain ditempatkan sebagai cita hukum, juga merupakan pandangan hidup bangsa Indonesia tentang hubungan antara manusia dengan Tuhan, manusia dengan sesama manusia, serta manusia dengan alam semesta yang berintikan keyakinan tentang tempat manusia individual di dalam masyarakat dan alam semesta. Pandangan hidup adalah pandangan atau penghayatan manusia tentang tempat dirinya dalam kerangka keseluruhan. la merupakan pangkal bertolak dari landasan kefilsafatan serta ukuran bagi norma kritik yang mendasari atau menjiwai 
Mahrus Ali, Fondasi Ilmu Hukum Berketuhanan: Analisis Filosofis terhadap Ontologi, Epistemologi,...

tata hukum. Oleh karena itu, pandangan hidup yang dianut akan memberikan koherensi dan pengarahan pada keseluruhan prosesproses sosial penormaan peraturan-peraturan hukum beserta dengan proses-proses penerapannya dalam kehidupan bermasyarakat (Sidharta, tt;1). Di dalam pandangan hidup terkandung konsep dasar mengenai kehidupan yang dicita-citakan oleh suatu bangsa, terkandung pikiran terdalam dan gagasan suatu bangsa, dan wujud kehidupan yang dianggap baik. Pada akhirnya, pandangan hidup suatu bangsa adalah suatu kristalisasi dari nilai-nilai yang dimiliki oleh bangsa itu sendiri, yang diyakini kebenarannya dan menimbulkan tekad pada bangsa itu untuk mewujudkannya (Saksono, 2007; 33).

\section{Nilai-nilai Ketuhanan}

Dengan dijadikannya Pancasila sebagai cita hukum dan pandangan hidup bangsa Indonesia, maka kajian terhadap nilai-nilai yang terkandung di dalam tiap-tiap sila Pancasila mutlak dilakukan secara berkesinambungan. Dalam kaitan dengan hal ini, pembaharuan, pembentukan dan penegakan hukum di Indonesia harus berpedoman kepada nilai-nilai Pancasila tersebut sembari pada saat yang sama tetap memberikan kemungkinan adopsi terhadap perkembangan hukum di tingkat global sepanjang sesuai dengan nilai-nilai tersebut.

Sebagai nilai yang berakar pada nilainilai kebudayaan dan nilai-nilai religius yang dimiliki bangsa Indonesia sendiri sebelum mendirikan negara (Surono dan Miftakhul Huda, 2011; 58), nilai yang terkandung pada tiap-tiap sila Pancasila merupakan suatu sistem nilai. Meskipun dalam setiap sila terkandung nili-nilai yang memiliki perbedaan antara satu dengan lainnya, namun kesemuanya itu tidak lain merupakan suatu kesatuan yang sistematis (Kaelan, 59). Dengan kata lain, kesatuan lima nilai fundamental Pancasila bersama-sama dengan berbagai nilai yang dijabarkan atau diderivasi berdasarkannya, mewujudkan sebuah sistem nilai, dan dielaborasi ke dalam berbagai asas hukum dan kaidah hukum yang keseluruhannya mewujudkan sebuah sistem hukum (tata hukum) (Sidharta, 2013; 98).
Secara eksplisit, nilai-nilai yang tekandung dalam Pancasila adalah nilai ketuhanan, nilai kemanusiaa, nilai persatuan, nilai kerakyatan, dan nilai keadilan sosial (Kaelan, 79-83). Dalam sila Ketuhanan Yang Maha Esa terkandung nilai bahwa negara yang didirikan adalah sebagai pengejawantahan tujuan manusia sebagai makhluk Tuhan Yang Maha Esa. Oleh karena itu, segala hal yang berkaitan dengan pelaksanaan dan penyelenggaraan negara bahkan moral negara, moral penyelenggara negara, politik negara, pemerintahan negara, hukum dan peraturan perundang-undangan negara, kebebasan dan hak asasi warga negara harus dijiwai nilai-nilai Ketuhanan Yang Maha Esa. Sila kemanusiaan sebagai dasar dalam kehidupan kenegaraan, kebangsaan, dan kemasyarakatan. Nilai kemanusiaan ini bersumber pada dasar filosofis antropologis bahwa hakikat manusia adalah susunan kodrat rokhani (jiwa) dan raga, sifat kodrat individu dan makhluk sosial, kedudukan kodrat makhluk pribadi berdiri sendiri dan sebagai makhluk Tuhan Yang Maha Esa. Nilai-nilai yang terkandung di dalam sila kedua Pancasila adalah bahwa negara harus menjunjung tinggi harkat dan martabat manusia sebagai makhluk beradab.

Dalam sila ketiga terkandung nilai bahwa negara adalah sebagai penjelmaan sifat kodrat manusia monodualis, yaitu sebagai makhluk individu dan makhluk sosial. Negara merupakan suatu persekutuan hidup bersama di antara elemen-elemen yang membentuk negara yang berupa suku, ras, kelompok golongan maupun kelompok agama. Oleh karena itu, perbedaan merupakan bawaan kodrat manusia dan sekaligus merupakan ciri khas elemen-elemen yang membentuk negara. konsekuensinya, negara adalah beranega ragam tetapi satu, mengikatkan diri dalam suatu persatuan yang dilukiskan dalam bhinneka tuggal ika, perbedaan dalam kesatuan dan kesatuan dalam perbedaan (Sidharta, 2013; 97).

Nilai demokrasi yang merupakan nilai yang terkandung dalam sila keempat Pancasila menghendaki agar negara adalah dari, oleh, dan untuk rakyat. Secara lebih operasional, nilai-nilai yang terkandung di dalam sila ini sebagai berikut; 1) adanya kebeba- 
san yang harus disertai dengan tanggung jawab baik terhadap masyarakat dan negara maupun terhadap Tuhan Yang Maha Esa; 2) menjunjung tinggi harkat dan martabat kemanusiaan; 3) menjamin dan memperkokoh persatuan dan kesatuan dalam hidup bersama; 4) mengakui perbedaan individu, kelompok, ras, suku, agama; 5) mengakui adanya persamaan hak yang melekat pada setiap individu, kelompok, ras, suku maupun agama; 6) mengarahkan perbedaan dalam suatu kerja sama kemanusiaan yang berada; 7) menjunjung tinggi asas musyawarah sebagai moral kemanusiaan yang beradab; dan 8) mewujudkan dan mendasarkan suatu keadilan dalam kehidupan sosial agar tercapat tujuan bersama.

Sebagai penutup dari nilai-nilai dalam sila Pancasila adalah nilai keadilan sosial. Keadilan di sini dimaknai sebagai keadilan dalam hubungan manusia dengan dirinya sendiri, manusia dengan manusia lain, manusia dengan masyarakat, bangsa dan negaranya, dan hubungan manusia dengan Tuhannya. Dari makna keadilan ini kemudian lahir tiga konsep keadilan, yaitu keadilan distributif, keadilan legal, dan keadilan komutatif. Keadilan distributif adalah suatu hubungan keadilan antara negara terhadap warganya, dalam arti negaralah yang wajib memenuhi keadilan bagi semua waganya atas dasar persamaan hak dan kewajiban. Keadilan legal adalah suatu hubungan keadilan antara warga negara terhadap negara. Pihak warga negaralah yang wajib memenuhi keadilan dalam bentuk mentaati hukum dan peraturan perundang-undangan yang berlaku dalam negara. Sedangkan keadilan komutatif mengenai hubungan keadilan antara warga negara yang satu dengan warga negara yang lain secara timbal balik.

Berdasarkan uraian di atas, tampak bahwa meskipun antara kelima sila Pancasila dengan nilai-nilai yang terkandung di dalamnya terpisah satu sama lain, namun ia merupakan satu kesatuan sistem nilai. Selain itu, sebagaimana dikemukakan oleh Hazairin, dari kelima sila yang terdapat dalam Pancasila, ada satu sila yang mempunyai posisi istimewa, yaitu sila Ketuhanan Yang Maha Esa karena sila ini tertelak di luar ciptaan akal-bu- di manusia. Hanya sila Ketuhanan Yang Maha Esa yang bukan hasil kebudayaan manusia. la adalah sesuatu yang abadi, yang kekal, tidak berubah-ubah, tidak dapat dipengaruhi oleh manusia, dan tidak dapat ditundukkan kepada kemauan dan keinginan manusia. Oleh karena itu, ia dijadikan landasan yang paling aman dan paling kokoh bagi Negara Republik Indonesia (Hazairin, 1985; 15-16).

Dengan mengacu kepada pendapat Hazairin di atas, dapat dinyatakan bahwa muara dari nilai-nilai Pancasila terletak pada nilai Ketuhanan Yang Maha Esa. Tanpa nilai ini, ilmu hukum Indonesia tidak memiliki arti apapun. Pemahaman terhadap keempat nilai lain yang terdapat dalam Sila kedua hingga keempat Pancasila tidak dapat dipisahkan dari pemahaman terhadap nilai Ketuhanan Yang Maha Esa. Nilai Ketuhanan yang terdapat dalam sila pertama ini menjadi perekat nilai-nilai yang terkandung dalam sila-sila berikutnya, atau ia meliputi dan menjiwai silasila berikutnya (Darmodiharjo dan Shidarta, 2014; 322). Karena ia menjadi perekat, maka uraian tentang nilai ketuhanan yang menjadi fondasi ilmu hukum ketuhanan mau tidak mau harus dibarengi dengan uraian terhadap nilai-nilai yang lain itu.

Selain sebagai perekat, nilai ketuhanan dalam Pancasila menunjukkan bahwa eksistensi negara, bangsa, dan manusia Indonesia berelasi dengan Tuhan yang diyakini sebagai sumber segala yang mulai, baik, dan adil. la merupakan suatu fundamen moral dan berdimensi religius yang menentukan pola dasar bagi seluruh kehidupan serta menentukan bagiamana negara, bangsa, dan orang Indonesia memandang dirinya serta kehidupannya. Disebutkan dalam hasil kesimpulan panitia kecil yang mencoba mengurai Pancasila sebagai berikut (Tanya, Parera dan Lena, 2015; 41, Panitia Kecil, 1977; 41):

"Dasar Ketuhanan Yang Maha Esa...memberi jiwa kepada usaha menyelenggarakan segala yang benar, adil, dan baik"...Manakala sewaktu-waktu kesasar dalam perjalanan, ada senantiasa terasa desakan gaib yang membimbing kembali ke jalan yang benar".

Sila Ketuhananya Yang Maha Esa, den- 
Mahrus Ali, Fondasi Ilmu Hukum Berketuhanan: Analisis Filosofis terhadap Ontologi, Epistemologi,...

gan merujuk kepada pernyataan di atas, berfungsi sebagai fundamen nilai-moral. Itulah sebabnya, para pendiri bangsa (founding fathers) tidak memaknai sila Ketuhanan itu terlalu teologis dan filosofis. la tidak ditampilkan sebagai konsep Ilahiah menurut klaim agama dan filsafat tertentu yang sarat dengan ortodoksi (Panitia Kecil, 1977; 42). la dimaknai dalam konteks kehidupan praksis, suatu kehidupan yang dicirikan dengan bagaimana nilai-nilai ketuhanan itu dipraktikkan dalam kehidupan sehari-hari, seperti bersikap adil terhadap sesama, berkata dan bertindak jujur, dan mempererat tali persaudaraan sehingga konflik sebisa mungkin dihindari karena bertentangan dengan nilai-nilai ketuhanan. Nilai ketuhanan dalam Pancasila tidak hanya sekedar hormat-menghormati agama masing-masing, melainkan memuat nilai seperti memimpin ke jalan kebenaran, keadilan, kebaikan, kejujuran, persaudaraan dan lainnya. Dari nilai-nilai itulah negara memperoleh fondamennya.

Berdasarkan uraian di atas, dapat disimpulkan bahwa nilai-nilai ketuhanan yang dijadikan dasar atau jiwa penyelenggaraan pemerintah termasuk pengembangan ilmu hukum tidak hanya berasal dari agama atau kepercayaan tertentu, melainkan berdasarkan prinsip-prinsip ajaran agama dan kepercayaan yang sifatnya universal. Semua agama dan kepercayaan yang diakui keberadaannya di Indonesia pasti mengajarkan kejujuran, kasih sayang, keadilan, kemanusiaan, musyawarah, dan mempererat tali persaudaraan, dan itulah esensi dari nilai-nilai ketuhanan.

\section{Ontologi Ilmu Hukum Berketuhanan}

Setiap ilmu pengetahuan bidang apapun termasuk bidang ilmu hukum harus memiliki dasar ontologis keilmuan yang jelas, karena hal ini akan berimplikasi pada bagaimana teori, konsep, dan metode dibangun. Aspek ontologis antara lain mempersoalkan apa yang merupakan hakikat dari realitas. Aneka jawaban yang diberikan terhadap pertanyaan-pertanyaan tentang hakikat realitas ini melahirkan sejumlah pendekatan. Ada yang melihat inti realitas sebagai materi, sementara yang lain melihatnya sebagai ide (gagasan). Pandangan monistis yang hanya memilih salah satu dari alternatif di atas, ditentang oleh aliran dualisme yang mengatakan hakikat realitas justru keduanya sekaligus (Sidharta, 2006; 71).

Dalam ilmu hukum berketuhanan, hukum dimaknai sebagai nilai. Nilai di sini adalah nilai-nilai ketuhanan yang digali dari nilai-nilai agama, nilai kepercayaan dan nilai-nilai budaya masyarakat Indonesia, yang bentuknya berupa nilai religius, nilai kemanusiaa, nilai persatuan, nilai demokrasi, dan nilai keadilan sosial (Surono dan Huda, 2011; 65). Pemaknaan hukum sebagai nilai pada hakikatnya bukan semata-mata memandang bahwa hukum adalah seperangkat norma yang dipositifkan dalam peraturan perundang-undangan, tetapi justru kepada nilai. Aspek norma merupakan aspek luar atau aspek lahiriah yang nampak dan terwujud dalam perumusan perundang-undangan. Sedangkan aspek nilai merupakan aspek dalam atau aspek batiniah/kejiwaan yang ada di balik atau di belakang norma (Arief, 2015; 47, Arief, 1994; 29-30). Hukum yang hanya dipandang sebagai norma bukanlah merupakan konsep hukum yang lengkap. la harus dibarengi dengan nilai-nilai. Dalam kaitan inilah, Prof. Moeljatno menyatakan bahwa tiap ilmu pengetahuan (termasuk ilmu hukum) yang tidak dibarengi dengan ilmu ketuhanan adalah tidak lengkap (Arief, 2015; 32). Ilmu ketuhanan di sini adalah nilai-nilai ketuhanan itu sendiri.

Hakikat hukum sebagai nilai menurut ilmu hukum berketuhanan berbeda dengan aliran-aliran dalam filsafat hukum yang berkembangan di dunia barat di dalam memandang hakikat hukum. Hukum kodrat (natural law) memandang hukum sebagai keadilan dan kebenaran, berlaku secara universal dan abadi (Rasjidi, 2001; 43, Finch, 1974; 21). Meskipun secara sepintas ada kesamaan antara hakikat hukum menurut ilmu hukum berketuhanan dengan hukum kodrat, namun keduanya tetap berbeda, yakni pada kuatnya nilai-nilai budaya masyarakat Indonesia sebagaimana tercantum dalam sila keempat Pancasila. Selain itu, ilmu hukum berketuhanan adalah ilmu hukum yang berbasis pada cita hukum dan pandangan hidup bangsa Indonesia yang telah dipraktikkan 
sejak lama oleh bangsa Indonesia. Sedangkan hukum alam melintasi sekat-sekat cita hukum dan pandangan hidup suatu bangsa. Pemikiran hukum kodrat tentang hakikat hukum ini ditentang oleh positivisme hukum (legal positivism), yang memandang hukum sebagai norma-norma positif dalam sistem perundang-undangan (Fletcher, 1996; 33; Thontowi, 2011: 205-206). Hakikat hukum menurut positivisme hukum ini sama dengan aliran utilitarianisme, yang memandang hukum sebagai norma-norma positif dalam perundang-undangan (Sidharta, 2006; 255). Nilai-nilai di balik norma positif itu sama sekali tidak diperhitungkan dan tidak dianggap sebagai hukum. Padahal, ilmu hukum berketuhanan justru menekankan pada nilai-nilai tersebut.

Dalam perkembangannya, hakikat hukum menurut positivisme hukum itu ditentang oleh realisme hukum yang mengkonsepsikan hukum sebagai pola perilaku hakim di dalam persidangan (Sudirman, 2007; 30). la merupakan manifestasi makna-makna simbolik pada pelaku sosial. Pertentangan antara positivisme hukum dan realisme hukum berakhir dengan kemunculan sociological jurispredence. Menurut aliran ini, hukum yang baik adalah hukum yang sesuai dengan hukum yang hidup di masyarakat. Hukum itu mencerminkan nilai-nilai yang hidup di masyarakat (Rasjidi dan Rasjidi, 2001; 66). Dengan kata lain, hukum positif itu hanya akan efektif jika selaras dengan hukum yang hidup dalam masyarakat (Salman, 2009; 72). Penekanan pada nilai yang hidup dalam masyarakat menunjukkan bahwa hakikat hukum dibatasi maknanya pada hukum yang nyata-nyata hidup dalam masyarakat terlepas dari apakah hukum itu sesuai dengan nilai-nilai ketuhanan.

Berbeda dengan hakikat hukum menurut sociological jurisprudence, mazhab sejarah memandang hukum itu harus bersumber dari kebiasan dan kesadaran umum masyarakat. Aturan hukum yang dibuat dan diterapkan hendaknya merupaan endapan dari jiwa hukum rakyat karena hanya dengan inilah, aturan itu bisa diterapkan dan berfungsi dengan baik di masyarakat. Hukum tumbuh dan berkembang sejalan dengan perkembangan rakyat, dan akhirnya berakhir dengan berakhirnya suatu bangsa (Salman, 2009; 72). Selain itu, adat istiadat bangsa hanya berlaku sebagai hukum sesudah disahkan oleh negara. Sama halnya dengan pengolahan hukum oleh kaum yuris, pikiran-pikiran mereka tentang hukum memerlukan pengesahan negara supaya berlaku sebagai hukum (Darmodiharjo dan Shidarta, 1995; 108). Penekanan pada adat istiadat suatu bangsa sebagai sumber hukum bisa jadi menafikan nilai-nilai ketuhanan yang justru menjiwai keberadaan hukum, dan inilah perbedaan antara mazhab sejarah dengan ilmu hukum berketuhanan.

Berdasarkan uraian di atas, hakikat ilmu hukum berketuhanan adalah ilmu hukum yang dikembangkan berbasis pada nilai-nilai ketuhanan. Oleh karena itu, ilmu hukum Indonesia adalah ilmu hukum yang tidak sekuler yakni ilmu hukum yang melepaskan diri nilai-nilai moral dan agama, melainkan ilmu hukum yang menjadikan nilai-nilai moral dan agama sebagai fondasi atau landasan dalam pembaharuan, pembentukan, dan penegakan hukum (Bello, 2013; 117).

\section{Epistemologi Ilmu Hukum Berketuhanan}

Epistemologi adalah pilar kedua ilmu pengetahuan setelah ontologi yang mempersoalkan tentang hakikat sumber pengetahuan dan kebenaran pengetahuan. Berdasarkan pemikiran ini, ilmu hukum berketuhanan memandang hukum tidak hanya berdasarkan rasio yang berkembang dari penguasa atau bukan hanya berdasarkan pada prinsip-prinsip hukum kodrat melainkan juga berdasarkan pada nilai

Bangsa Indonesia telah menentukan suatu pilihan melalui pada pendiri bangsa (the founding fathers) Indonesia, bahwa dalam hidup kenegaraan dan kebangsaan bangsa Indonesia mengangkat dan merumuskan Pancasila sebagai core philosophy yang ditempatkan sebagai dasar falsafah negara. Oleh karena itu, nilai-nilai Pancasila adalah sebagai sumber nilai dalam realisasi normatif dan praksis dalam kehidupan kenegaraan dan kebangsaan. Nilai-nilai Pancasila merupakan das solle bagi bangsa Indonesia, sehinga seluruh derivasi normatif dan praksis ber- 
Mahrus Ali, Fondasi Ilmu Hukum Berketuhanan: Analisis Filosofis terhadap Ontologi, Epistemologi,...

basis pada nilai-nilai Pancasila (Kaelan, 2013; 517). Dalam konteks ilmu hukum berketuhanan, nilai-nilai Pancasila yang menjadi sumber hukum (pengetahuan) terletak pada nilai Ketuhanan Yang Maha Esa (Tuhan itu sendiri) karena ia meliputi dan menjiwai semua nilai yang lain. Ini artinya, semua derivasi normatif dan praksis yang tidak berbasis pada nilai-nilai ketuhanan tidak dapat disebut berasal dari nilai-nilai Pancasila.

Konsepsi bahwa nilai ketuhanan sebagai hakikat sumber hukum Indonesia menicsayakan suatu pemikiran bahwa antara hukum dan nilai-nilai tidak dapat dipisahkan. Hukum tanpa nilai yang mendasarinya tidak memiliki makna apapun. Nilai ketuhanan, nilai kemanusiaan, nilai persatuan, nilai kerayataan, dan nilai keadilan sosial harus menjadi ruh dan menjiwai semua pembentukan sistem hukum Indonesia. Adanya hubungan antara hukum dengan nilai ini sebagai basis epistemologis ilmu hukum Indonesia tampaknya sama dengan aliran hukum kodrat yang menghendaki berlakunya hukum positif dipertimbangkan berdasarkan nilai dari isi peraturan (materi hukum); apakah isi dari suatu hukum positif sesuai dengan hukum yang ideal (prinsip-prinsip moral) yang kedudukannya diandaikan lebih tinggi di atas hukum positif. Oleh karena itu, terdapat hubungan yang esensial antara hukum dan moral (there is an essential connection between law and morality) (Murphy dan Coleman, 1990; 11). Validitas moral merupakan prasyarat yang dibutuhkan secara logis bagi adanya validitas hukum (Murphy dan Coleman, 1990; 15). Prasyarat moral ini melahirkan pernyataan bahwa hukum yang tidak adil bukan hukum (an unjust law is not law/lex iniusta non est lex) (Patterson, 1999; 226). Selain itu, moral sebagai prasyarat hukum ini merupakan bagian dari tatanan alam (Murphy dan Coleman, 1990; 15). Hanya saja, ilmu hukum berketuhanan tidak hanya didasarkan pada nilai-nilai moralitas yang universal, tapi juga nilai-nilai budaya bangsa Indonesia.

Karena hukum tidak mungkin lepas dari nilai-nilai moral, maka ilmu hukum berketuhanan berbeda secara diametral dengan positivisme hukum yang menganggap berlakunya hukum positif bukan dari segi mate- rinya, melainkan dari segi formalnya. Hukum ditaati bukan karena isinya dinilai baik atau adil, melainkan karena telah ditetapkan oleh penguasa yang sah. Positivisme hukum menghendaki hukum terpisah dari moral. Austin dan Kelsen sebagai pentolan aliran ini menolak hukum terkontaminasi anasir-anasir non hukum seperti moral (nilai, pen) (Putro, 2011; 119). Demikian juga dengan utilitarianisme, yang menekankan pada aspek kemanfaatan pada golongan terbanyak yang pada akhirnya mengakibatkan hukum menjadi elitis. Nilai-nilai moralitas dikesampingkan sepanjang hukum sudah mendatangkan manfaat bagi kebanyakan orang.

Ilmu hukum berketuhanan agak mirip dengan aliran hukum kodrat dan mazhab sejarah, yaitu terletak pada adanya keterkaitan antara hukum dengan nilai-nilai moralitas dan nilai-nilai budaya bangsa. Hanya saja, moralitas dalam aliran hukum kodrat dipengaruhi oleh cara pandang gereja waktu itu. Sedangkan moralitas dalam ilmu hukum berketuhanan mengacu kepada nilai-nilai ketuhanan yang telah dipraksiskan dalam kehidupan bernegara dan berbangsa bangsa Indonesia.

Dalam kaitannya dengan kebenaran pengetahuan, ilmu hukum berketuhanan beranjak dari kebenaran firman Tuhan yang diwujudkan dalam bentuk nilai-nilai Pancasila yang selaras dengan nilai-nilai budaya bangsa Indonesia. Oleh karena itu, kebenaran menurut ilmu hukum berketuhanan tidak hanya mengacu kepada kebenaran korespondensi, kebenaran koherensi, dan kebenaran pragmatis (Putro, 2011; 276-279), melainkan menjadikan ketiga kebenaran itu menyatu di bawah payung kebenaran ilahiah.

\section{Aksiologi Ilmu Hukum Berketuhanan}

Aksiologi mempelajari nilai yang hendak dituju dari suatu ilmu. Dengan kata lain, pertanyaan mendasar mengenai aspek aksiologis suatu ilmu adalah untuk apa ilmu pengetahuan itu dibangun dan dikembangkan? Dalam konteks hukum, aksiologi terkait tujuan atau nilai-nilai tertentu yang hendak dituju dari suatu hukum, seperti tujuan hukum adalah untuk mencapai kepastian hukum, kemanfaatan hukum atau keadilan hukum. 
Ilmu hukum berketuhanan juga memiliki tujuan/nilai-nilai tertentu yang hendak dicapai yang berbeda dengan tujuan/nilai-nilai dalam aliran-aliran filsafat hukum yang lahir di dunia barat.

Untuk mengetahui dan menemukan nilai-nilai aksiologis ilmu hukum berketuhanan adalah dengan memahami dan menggali nilai-nilai yang terkandung dalam tiap-tiap sila Pancasila. Hal ini karena Pancasila dijadikan cita hukum dan pandangan hidup bangsa Indonesia. Konsekuensinya, ilmu hukum Indonesia yang berciri ketuhanan harus mengacu kepada cita hukum dan pandangan hidup bangsa Indonesia yang tercermin dalam nilai-nilai Pancasila. Nilai-nilai yang terkandung dalam kelima sila Pancasila itulah yang merupakan aksiologi ilmu hukum berketuhanan, antara lain nilai religius, nilai kemanusiaan, nilai kebangsaan/nasionalistik/ persatuan, nilai musyawarah, dan nilai keadilan sosial. Nilai-nilai tersebut merupakan satu kesatuan yang tidak dapat dipisahkan satu sama lain yang membentuk kesatuan sistem nilai.

Nilai religius menghendaki agar ilmu hukum Indonesia mengakui nilai-nilai hukum Tuhan selain hukum kodrat, hukum etis, dan hukum filosofis dalam kehidupan bernegara. Implementasi dari nilai ini dapat diwujudkan melalui pemberlakuan nilai-nilai hukum tersebut sebagai sumber derivasi bagi pengembangan ilmu hukum Indonesia (Wahyudi dkk, 2009; 58). Nilai kemanusiaan berkaitan dengan perhormatan terhadap harkat dan martabat manusia. Ilmu hukum Indonesia harus mampu memanusiakan manusia. Di bidang hukum pidana, nilai ini secara operasional terlihat pada ide individualisasi pidana yang bentuknya antara lain; 1) pertanggungjawaban pidana bersifat pribadi (asas personal); 2) ada kelonggaran/fleksibilitas bagi hakim dalam memilih sanksi pidana (jenis maupun berat-ringannya sanksi) (asas elasticity/flexibility of sentencing); 3) ada kemungkinan modifikasi pidana (perubahan/ penyesuaian) dalam pelaksanaannya (asas modification of sanction); 4) asas permaafan (Arief, 2009; 23).

Nilai kebangsaan bermakna bahwa ilmu hukum berketuhanan, di samping di- dasarkan pada nilai-nilai religius, juga harus mencerminkan sifat dan watak bangsa Indonesia yang pluralistik. Selain itu, dengan menjadikan bhinneka tunggal ika semboyan bangsa Indonesia, maka ilmu hukum berketuhanan juga harus memperhatikan keragaman penduduk, agama, suku dan golongan, kondisi khusus daerah, dan budaya (Arief, 2009; 23). Pengakuan terhadap hukum tidak tertulis (hukum yang hidup dalam masyarakat) merupakan ciri ilmu hukum berketuhanan yang memiliki kedudukan yang sama dengan hukum tertulis. Hal ini karena sebelum Indonesia merdeka, hukum yang hidup dalam masyarakat ini telah ada dan dipraktikkan oleh masyarakat Indonesia. Dengan kata lain, pengakuan terhadap hukum yang hidup dalam masyarakat merupakan konkritisasi dalam nilai kerakyatan yang termaktub dalam sila keempat Pancasila.

Nilai keadilan sosial menghendaki bahwa ilmu hukum Indonesia didesain untuk mewujudkan keadilan bagi seluruh rakyat Indonesia (Kaelan, 2013; 388-389). Implikasinya, sistem hukum nasional yang berbasis pada nilai ini tidak boleh elitis atau bahkan feodal, dalam arti hanya menguntungkan pihak-pihak tertentu dan menyengsarakan pihak lain. secara lebih operasional, nilai keadilan ini menghasilkan beberapa prinsip, antara lain prinsip persamaan, prinsip objektifitas, prinsip tidak pilih kasih, dan prinsip tidak berpihak (Arief, 2009; 20). Ilmu hukum berketuhanan memandang bahwa semua manusia adalah sama di hadapan Tuhan, dan yang membedakan adalah kadar ketaqwaan masing-masing. Di dalam prinsip objektifitas terkandung makna pembentukan hukum harus dijauhkan dari hawa nafsu karena keberadaannya menyimpang dari keadilan. Isi hukum tidak boleh hanya menguntungkan penganut agama, golongan, suku, dan ras tertentu dan menyengsarakan penganut agama, golongan, suku, dan ras yang lain.

Berdasarkan uraian di atas, tampak bahwa nilai yang hendak diwujudkan oleh ilmu hukum berketuhanan sedemikian komperensif yang tidak hanya mengacu kepada satu atau dua nilai, melainkan semua nilainilai bangsa Indonesia baik yang religius maupun yang kultural. Nilai-nilai ini sudah 
Mahrus Ali, Fondasi Ilmu Hukum Berketuhanan: Analisis Filosofis terhadap Ontologi, Epistemologi,...

dipraktikkan sejak lama oleh bangsa Indonesia sebelum Indonesia merdeka. Artinya, meskipun nilai-nilai itu universal dan abstrak, tapi ia sudah dipraktikkan, mendarah daging, dan menjiwai kehidupan sehari-hari bangsa Indonesia.

Jika dibandingkan dengan nilai yang hendak diwujudkan yang terdapat dalam aliran-aliran filsafat hukum yang berkembang di dunia barat, akan tampak perbedaannya dengan (aksiologi) ilmu hukum berketuhanan. Pertama, nilai yang hendak diwujudkan bersifat parsial, dalam arti hanya menekankan pada nilai tertentu dan melepaskan nilai yang lain. Aliran hukum kodrat hanya menekankan hanya pada nilai keadilan, positivisme hukum hanya menekankan pada nilai kepastian hukum (undang-undang), utilitarianisme pada nilai kepastian yang diikuti nilai kemanfaatan hukum, realisme hukum pada nilai kemanfaatan, sociological jurisprudence pada nilai kemanfaatan dan kepastian hukum secara simultan, dan mazhab sejarah yang menekankan pada nilai kemanfaatan dan keadilan secara simultan (Sidharta, 2006; 240, 249, 255, 259, 268, dan 275). Kedua, nilai kepastian hukum yang dimaksudkan dan ingin diwujudkan baik oleh positivisme hukum, utilitarianisme, maupun sociological jurisprudence dibatasi maknanya hanya pada kepastian undang-undang. Hukum direduksi maknanya hanya sebatas undang-undang. Dalam ilmu hukum berketuhanan, kepastian hukum tidak bisa dipisahkan dari keadilan. Itulah mengapa istilah yang digunakan bukan kepastian hukum melainkan kepastian hukum yang adil. Di sini hukum tidak hanya dimaknai sebagai undang-undang, tapi juga keadilan yang didasarkan pada nilai-nilai ketuhanan dan nilai-nilai budaya bangsa Indonesia.

Ketiga, kecuali aliran hukum kodrat yang dipengaruhi ajaran-ajaran gereja, pemikiran yang mendasari sejumlah nilai yang hendak diwujudkan dalam aliran filsafat hukum dipengaruhi oleh hukum yang sekuler, yang memisahkan antara agama dengan negara (pemisahaan antara hukum dengan nilai moralitas religius). Sedangkan nilai yang hendak diwujudkan oleh ilmu hukum berketahuan berangkat dari titik anjak bahwa tidak ada pemisahaan antara negara dengan agama. Bahkan, nilai-nilai agama menjiwai hukum negara. Hukum yang tidak berbasis pada nilai-nilai moral religius bukanlah hukum, sehingga ia tidak memiliki validitas apapun dalam praksis.

\section{Simpulan}

Penelitian ini menghasilkan dua kesimpulan. Pertama, nilai ketuhanan dalam Pancasila tidak sekedar hormat-menghormati agama masing-masing, melainkan juga memuat nilai berupa memimpin ke jalan kebenaran, keadilan, kebaikan, kejujuran, persaudaraan dan lainnya. Sebagai nilai yang ditempatkan pada posisi pertama, nilai ketuhanan seharusnya berimplikasi pada perlunya dikembangkan ilmu hukum berketuhanan, suatu ilmu yang tidak dapat dilepaskan dari nilai-nilai ilahiah. Dalam kaitannya dengan ilmu hukum berketuhanan, hukum dimaknai sebagai nilai, yaitu nilai-nilai ketuhanan yang digali dari nilai-nilai agama, nilai kepercayaan dan nilai-nilai budaya masyarakat Indonesia, yang bentuknya berupa nilai religius, nilai kemanusiaa, nilai persatuan, nilai demokrasi, dan nilai keadilan sosial.

Dalam kaitannya dengan kebenaran pengetahuan, ilmu hukum berketuhanan beranjak dari kebenaran firman Tuhan yang diwujudkan dalam bentuk nilai-nilai Pancasila yang selaras dengan nilai-nilai budaya bangsa Indonesia. Oleh karena itu, kebenaran menurut ilmu hukum berketuhanan tidak hanya mengacu kepada kebenaran korespondensi, kebenaran koherensi, dan kebenaran pragmatis, melainkan menjadikan ketiga kebenaran itu menyatu di bawah payung kebenaran ilahiah. Aksiologi ilmu hukum berketuhanan mengacu kepada cita hukum dan pandangan hidup bangsa Indonesia yang tercermin dalam nilai-nilai Pancasila. Nilai-nilai yang terkandung dalam kelima sila Pancasila itulah yang merupakan aksiologi ilmu hukum berketuhanan, antara lain nilai religius, nilai kemanusiaan, nilai kebangsaan/ nasionalistik/persatuan, nilai musyawarah, dan nilai keadilan sosial.

Kedua, meskipun secara sepintas ontologi ilmu hukum berketuhanan sama den- 
gan hakikat hukum menurut aliran hukum kodrat, tapi nilai dalam ilmu hukum berketuhanan berbasis pada cita hukum dan pandangan hidup bangsa Indonesia yang telah dipraktikkan sejak lama oleh bangsa Indonesia. Sedangkan hukum alam melintasi sekatsekat cita hukum dan pandangan hidup suatu bangsa. Penekanan pada nilai-nilai luhur bangsa Indonesia inilah yang tidak ditemukan baik pada aliran positivisme hukum, realisme hukum maupun sociological jurisprudence.

Nilai-nilai yang terkandung dalam ilmu hukum berketuhanan sudah sudah dipraktikkan sejak lama oleh bangsa Indonesia sebelum Indonesia merdeka. Artinya, meskipun nilai-nilai itu universal dan abstrak, tapi ia sudah dipraktikkan, mendarah daging, dan menjiwai kehidupan sehari-hari bangsa Indonesia. Konteks inilah yang membedakannya dengan aliran-aliran dalam filsafat hukum yang hanya menekankan pada nilai yang bersifat parsial,dalam arti hanya menekankan pada nilai tertentu dan melepaskan nilai yang lain. Aliran-aliran dalam filsafat hukum, kecuali aliran hukum alam, juga dipengaruhi oleh hukum yang sekuler.

\section{Daftar Pustaka}

Arief Sidharta, Bernard. 2000. Refleksi tentang Struktur IImu Hukum Sebuah Penelitian tentang Fundasi Kefilsafatan dan Sifat Keilmuan IImu Hukum Sebagai Landasan Pengembangan Ilmu Hukum Nasional Indonesia. Cetk. Kedua, Bandung: Mandar Maju.

Arief Sidharta, Bernard. 2013. Ilmu Hukum Indonesia Upaya Pengembangan Ilmu Hukum Sistematik yang Responsif terhadap Perubahan Masyarakat. Cetk. Pertama, Yogyakarta: Genta Publishing, Yogyakarta

Arief Sidharta, Bernard. tt. Filsafat Hukum Pancasila, Bahan Kuliah Program Pascarjana Magister Hukum, Fakultas Hukum UII, tidak diterbitkan.

Bari Azed, Abdul "Aliran Sociological Jurisprudence dan Cita-cita Pancasila di Bidang Hukum", dalam Rasjidi, Lili dan Sidharta, B. Arief. 1989. Filsafat Hukum Mazhab dan Refleksinya. Bandung: CV. Remaja Karya

C.K.L. Bello, Petrus. 2013. Ideologi Hukum Refleksi Filsafat atas Ideologi di Balik Hukum, Bogor: Insan Merdeka.
Darmodiharjo, Darji dan Shidarta. 2014. Pokok-pokok Filsafat Hukum Apa dan Bagaimana Filsafat Hukum Indonesia, Cetk Keduabelas, Jakarta: Gramedia.

Dwi Putro, Widodo. 2011. Tinjauan Kritis-Filosofis terhadap Paradigma Positivisme Hukum, Disertasi, Jakarta: Fakultas Hukum Universitas Indonesia.

Finch, John. 1974. Introduction to Legal Theory. London: Sweet \& Maxwell.

Hazairin. 1985. Demokrasi Pancasila, Cetk. Kelima, Jakarta: Bina Aksara

Kaelan. 2004. Pendidikan Pancasila, Yogyakarta: Paradigma.

Kaelan. 2013. Negara Kebangsaan Pancasila Kultural, Historis, Filosofis, Yuridis, dan Aktualisasinya. Cetk. Pertama, Yogyakarta: Paradigma.

L. Tanya, Bernard, Parera, Theodorus Yosep dan Lena, Samuel F. 2015. Pancasila Bingkai Hukum Indonesia, Yogyakarta: Genta Press.

Murphy, Jeffrie G. dan Coleman, Jules L.. 1990. Philosophy of Law an Introduction to Jurisprudence, Edisi Revisi, London: Westview Press.

Nawai Arief, Barda. 1994. Beberapa Aspek Pengembangan Ilmu Hukum Pidana (Menyongsong Generasi Baru Hukum Pidana Indonesia), Pidato Pengukuhan Guru Besar dalam Ilmu Hukum Pidana pada Fakultas Hukum Universitas Diponegoro, Semarang, 25 Juni 1994

Nawawi Arief, Barda. 2009. Pembaharuan Hukum Pidana dalam Konteks Pancasila, Seminar Nasional Implementasi Ide-ide Dasar Pancasila dalam Pembaharuan Hukum Pidana Indonesia, Diselenggarakan Oleh Universitas Trunojoyo, Bangkalan, 9 Nopember

Nawawi Arief, Barda. 2015. Ilmu Hukum Pidana Integralistik (Pemikiran Integratif dalam Hukum Pidana), Semarang: Pustaka Magister.

Nawawi Arief, Barda. 2015. Pembangunan Sistem Hukum Nasional (Indonesia). Semarang: Pustaka Magister

Notonegoro. 1980. Pancasila Secara Ilmiah Populer, Jakarta: CV. Panjturan Tudjuh.

P. Fletcher, George. 1996. Basic Concepts of Legal Thought. New York: Oxford University Press.

Panitia Kecil. 1977. Uraian Pancasila, Jakarta: Mutiara

Patterson, Dennis (editor). 1999. A Companion to Philosophy of Law and Legal Theory. United Kingdom: Blackwell Publishers.

Rahardjo, Satjipto. 2007. Biarkan Hukum Mengalir. Jakarta: Kompas.

Rasjidi, Lili dan Rasjidi, Ira. 2001. Dasar-dasar Filsafat 
Mahrus Ali, Fondasi Ilmu Hukum Berketuhanan: Analisis Filosofis terhadap Ontologi, Epistemologi,...

dan Teori Hukum, Cetk, Ketujuh, Bandung: Citra Aditya Bakti

Saksono, Gatut. 2007. Pancasila Seokarno. Yogyakarta: Rumah Belajar Yabinkes

Salman, Otje. 2009. Filsafat Hukum (Perkembangan dan Dinamika Masalah), Bandung: Refika Aditama.

Sidharta. 2006. Karakteristik Penalaran Hukum dalam Konteks Keindonesiaan, Bandung: CV. Utomo

Soejadi. 1999. Pancasila Sebagai Sumber Tertib Hukum Indonesia, Yogyakarta: Lukma Offset.

Soendari, Siti dan Udayati, Agni (Editor). 1996. Hukum Adat (dalam Alam Kemerdekaan Nasional dan Persoalannya Menghadapi Era Globalisasi). Surabaya: Ubhara Press

Sudirman, Antonius. 2007. Hati Nurani Hakim dan Putusannya Suatu Pendekatan dari Perspektif IImu Hukum Perilaku Kasus Hakim Bismar Siregar.
Bandung: PT. Citra Aditya Bakti, Bandung

Surono dan Huda, Miftakhul. 2011. Prosiding Sarasehan Nasional 2011 tentang Impelementasi Nilai-nilai Pancasila dalam Menegakkan Konstitusionalitas Indonesia, Cekt. Pertama, Jakarta: Sekretariat Jenderal dan Kepaniteraan Mahkamah Konstitusi.

Thontowi, J., Pengembangan Ilmu Hukum Berbasis Religiuos Science: Dekonstruksi Filsosofis Pemikiran Hukum Positivistik, Pandecta: Research Law Journal, Vol. 6 No. 2 Juli 2011.

Wahana, Paulus. 1993. Filsafat Pancasila, Yogyakarta: Kanisius.

Wahyudi, Agus dkk (editor). 2009. Proceeding Kongres Pancasila Pancasila dalam Berbagai Perspektif. Jakarta: Sekretariat Jenderal dan Kepaniteraan Mahkamah Konstitusi. 